\title{
PERBEDAAN KEASAMAN AIR SUSU IBU PERAH (ASIP) BERDASARKAN LAMA PENYIMPANAN
}

DIFFERENCE OF DAIRY MILK WATER (ASIP) BASED ON THE STORAGE

Dian Nintyasari Mustika ${ }^{1}$, Siti Nurjanah ${ }^{2}$, Yuliana Noor Setiawati Ulvie ${ }^{3}$

1,2,3 Fakultas Ilmu Kesehatan dan Keperawatan Universitas Muhammadiyah Semarang

Email : dian.nintya@unimus.ac.id

\begin{abstract}
ABSTRAK
Pemberian ASI di Indonesia belum dilaksanakan sepenuhnya sehingga perlu dilakukan upaya untuk meningkatkan perilaku menyusui pada ibu yang memiliki bayi khususnya pemberian ASI eksklusif. Salah satu hal yang menghambat pemberian ASI eksklusif seringkali dialami oleh ibu pekerja, di antaranya adalah pengetahuan dan kondisi yang kurang memadai bagi para ibu yang bekerja. Ibu pekerja harus memerah asi selama jam kerja bila ingin memberikan asi secara eksklusif. Penyimpanan ASIP harus memperhatikan level suhu dan durasi waktu penyimpanan agar tetap aman dikonsumsi bayi. Tujuan penelitian ini adalah mengetahui perbedaan keasaman ASIP berdasarkan lama penyimpanan. Populasi dalam penelitian ini adalah ibu pekerja yang memberikan ASI lewat ASI Perah. Sampel dalam penelitian ini adalah ASI dari Ibu Pekerja. Metode penelitian ini adalah metode kuantitatif secara deskriptif. Manfaat dari hasil penelitian ini yaitu diharapkan para ibu tidak ragu memberikan ASI eksklusif pada bayinya, para ibu pekerja bisa menyimpan ASIP nya di cooler bag atau lemari pendingin sehingga ibu pekerja masih tetap bisa memberikan ASI eksklusif selama 6 bulan dan dilanjutkan hingga bayi berusia 2 tahun.
\end{abstract}

Kata kunci: ASI perah, keasaman.

\section{ABSTRACT}

The provision of breastmilk in Indonesia has not been fully implemented so that it is need more efforts to improve breastfeeding behavior in mothers who have babies, especially exclusive breastfeeding. Some inhibiting factors of exclusive breastfeeding which often experienced by working mothers, including insufficient knowledge and conditions for working mothers. Working mom must milking during working hours if they want to give breast milk exclusively. Mother must pay attention to the temperature level and duration of breastmilk storage so that the breastmilk is safe to be consumed by the baby. The purpose of this study is to determine the differences in breastmilk acidity based on storage time. The population in this study are working mothers who breastfed their babies. The sample in this study was breastmilk from the working mother. The research method used in this study is descriptive quantitative method. The benefit of this study are to motivate the working mom to give exclusive breastfeeding to their babies, working mothers can store their breastmilk in a cooler bag so that they can still provide exclusive breastfeeding for 6 months and continue until 2 years.

Keywords: Dairy breast milk, acidity. 


\section{PENDAHULUAN}

Peraturan pemerintah Nomor 33 pasal 2 Tahun 2012 Tentang ASI Eksklusif yaitu menjamin pemenuhan hak bayi untuk mendapatkan ASI eksklusif sejak dilahirkan sampai dengan berusia 6 (enam) bulan dengan memperhatikan pertumbuhan dan perkembangannya, memberikan perlindungan kepada ibu dalam memberikan ASI eksklusif kepada bayinya dan meningkatkan peran dan dukungan keluarga, masyarakat, pemerintah daerah dan pemerintah terhadap ASI eksklusif (Kemenkes RI, 2012).

Kebijakan Nasional untuk memberikan ASI eksklusif selama 6 bulan telah ditetapkan dalam SK Menteri No. 450/Menkes/SK/IV/2004 (Depkes RI, 2010). Pemberian ASI eksklusif juga telah diatur dalam Peraturan Bersama Menteri Negara Pemberdayaan Perempuan, Menteri Tenaga Kerja dan Transmigrasi, dan Menteri Kesehatan No. 48/MEN.PP/XII/2008, PER.27/MEN/XII/2008, dan 1177/MENKES/PB/XII/2008 Tahun 2008 tentang Peningkatan Pemberian Air Susu Ibu Selama Waktu Kerja di Tempat Kerja ("Peraturan Bersama"). Dalam Peraturan Bersama tersebut antara lain disebutkan bahwa Peningkatan Pemberian ASI selama waktu kerja di tempat kerja adalah program nasional untuk tercapainya pemberian ASI eksklusif 6 (enam) bulan dan dilanjutkan pemberian ASI sampai anak berumur 2 (dua) tahun. Tujuan peraturan bersama ini antara lain adalah memberi kesempatan kepada pekerja perempuan untuk memberikan atau memerah ASI selama waktu kerja dan menyimpan ASI perah untuk diberikan kepada anaknya, memenuhi hak pekerja perempuan untuk meningkatkan kesehatan ibu dan anaknya, memenuhi hak anak untuk mendapatkan ASI guna meningkatkan gizi dan kekebalan anak, dan meningkatkan kualitas sumber daya manusia sejak dini.

Data Profil Kesehatan Jawa Tengah tahun 2015 menunjukkan cakupan pemberian ASI eksklusif sekitar 61,6\%, terjadi peningkatan dibandingkan dengan tahun 2014 yaitu $60,7 \%$ dan tahun 2013 yaitu 52,99\%. Kabupaten/kota dengan presentase pemberian ASI eksklusif terrendah adalah Kota Semarang yaitu $6,72 \%$, diikuti Kudus $13,1 \%$ dan Tegal $33,4 \%$. Permasalahannya masih banyak instansi/perusahaan yang mempekerjakan perempuan akan tetapi tidak memberikan kesempatan bagi ibu yang memiliki bayi 0 6 bulan untuk melaksanakan pemberian ASI secara eksklusif, hal ini terbukti dengan tidak adanya ruang laktasi dan perangkat pendukungnya. Permasalahan lainnya yaitu masih banyak tenaga kesehatan di tingkat layanan yang belum peduli atau belum berpihak pada pemenuhan hak bayi untuk mendapatkan ASI eksklusif, yaitu dengan masih mendorong untuk memberikan susu formula pada bayi 0-6 bulan, dan juga belum maksimalnya kegiatan edukasi, sosialisasi, advokasi dan kampanye terkait pemberian ASI. (Profil kesehatan Provinsi Jawa Tengah 2015).

Apabila ibu pekerja ingin memberikan ASI secara eksklusif maka mereka harus memerah ASI selama jam kerja. Hal ini tidak mudah karena instansi/perusahaan harus menyediakan perangkat pendukungnya. Minimnya sarana yang disediakan untuk ibu menyusui, membuat ibu pekerja menjadi enggan untuk memberikan ASI eksklusif pada bauh hatinya. Penyimpanan ASIP harus memperhatikan level suhu dan durasi waktu penyimpanan agar tetap aman dikonsumsi bayi. Penyimpanan ASIP dalam suhu ruang $15^{0} \mathrm{C}$, aman dikonsumsi dalam 24 jam. Sedangkan untuk suhu ruang $19-22{ }^{\circ} \mathrm{C}$ ASIP bertahan selama 10 jam. Suhu ruang $25{ }^{\circ} \mathrm{C}$, 
sebaiknya simpan ASIP selama 4-8 jam. Jika ASIP segar disimpan dalam kulkas dengan suhu $0-4{ }^{0} \mathrm{C}$, ASI bisa bertahan hingga 3-8 hari. Sedangkan waktu penyimpanan ASIP segar di freezer tergantung model piranti tersebut. Jika disimpan dalam freezer di lemari es satu pintu, ASIP aman dikonsumsi hingga dua minggu. Sedangkan untuk freezer pada lemari es dua pintu, waktu penyimpanan, hingga 3-4 bulan. Jika disimpan di freezer khusus dengan di bawah $18{ }^{\circ} \mathrm{C}$,

dengan keasaman Air Susu Ibu Perah (ASIP) yang disimpan di cooler bag. Hasil penelitian ini dimaksudkan, agar para ibu pekerja tidak ragu lagi untuk memberikan ASI eksklusif pada bayinya.

ASIP aman disimpan hingga 6-12 bulan. Cooler bag menjadi alternatif untuk menyimpan ASIP apabila tidak tersedia lemari pendingin di tempat ibu bekerja. Sehingga, ASI ekslusif tetap dapat dijalankan selama 6 bulan dan dilanjutkan hingga bayi berusia 2 tahun. (Fazriyati, 2010).

Berdasarkan hal tersebut, maka peneliti tertarik untuk melakukan penelitian tentang hubungan lama penyimpanan

\section{METODE PENELITIAN}

Metode penelitian yang digunakan dalam penelitian ini adalah metode kuantitatif secara deskriptif. Sasaran dalam penelitian ini adalah ibu pekerja yang mempunyai bayi usia 3 - 6 bulan, sampel sejumlah 6 orang. Pengukuran keasaman ASI dilakukan sesuai dengan perlakuan penyimpanan dengan cara alat PH meter tipe HI 8424 Micro Computer dimasukkan ke dalam sampel.

\section{HASIL PENELITIAN PEMBAHASAN}

\section{a. Karakteristik Responden}

Responden dalam penelitian ini adalah ibu yang menyusui bayinya kurang dari 6 bulan sebanyak 6 orang.

\section{b. Umur Responden}

Tabel 1 Distribusi responden berdasarkan umur

\begin{tabular}{ccc}
\hline $\begin{array}{c}\text { Umur } \\
\text { (tahun) }\end{array}$ & Frekuensi & $\begin{array}{c}\text { Persentase } \\
(\%)\end{array}$ \\
\hline $20-35$ & 5 & 83,33 \\
$>35$ tahun & 1 & 16,67 \\
Jumlah & 61 & 100 \\
\hline
\end{tabular}

Berdasarkan tabel 1 didapatkan hasil penelitian bahwa sebagian besar umur responden yaitu umur $20-35$ tahun $(83,33 \%)$. Berdasarkan Arikunto (2006), terdapat tahap usia dewasa yakni dewasa awal (20-25tahun), dewasa muda (26-30 tahun), dan dewasa akhir (31-35 tahun). Dari hasil penelitian yang dilakukan oleh Herawati (2010), bahwa faktor umur berpengaruh dimana pencegahan infeksi luka lebih cepat terjadi pada usia muda. Dalam penelitian ini menunjukan bahwa sebagian usia responden termasuk dalam usia dewasa muda yakni antara usia 26-30 tahun. Hal ini menunjukan bahwa masyarakat telah paham mengenai usia reproduktif dan berfikir mengenai kesehatan salah satunya seorang ibu siap (hamil, melahirkan, nifas dan mengasuh anak).

\section{c. Jarak rumah Responden dengan Kantor}

Tabel 2 Distribusi responden berdasarkan jarak rumah dengan kantor

\begin{tabular}{ccc}
\hline $\begin{array}{c}\text { Jarak } \\
(\mathbf{k m})\end{array}$ & Frekuensi & $\begin{array}{c}\text { Persentase } \\
(\%)\end{array}$ \\
$<5$ & 3 & 50 \\
$>=5$ & 3 & 50 \\
Jumlah & 6 & 100 \\
\hline
\end{tabular}

Berdasarkan tabel 2 didapatkan hasil penelitian bahwa sebagian responden mempunyai jarak rumah dengan kantor 
$<5 \mathrm{Km}(50 \%)$. Jarak rumah dengan kantor lumayan dekat, sehingga ASIP aman jika dibawa perjalan pulang dari kantor ke rumah.

\section{d. Waktu tempuh Responden dengan Kantor}

Tabel 3 Distribusi responden berdasarkan waktu yang dibutuhkan ke kantor

\begin{tabular}{ccc}
\hline $\begin{array}{c}\text { Waktu } \\
\text { (menit) }\end{array}$ & Frekuensi & $\begin{array}{c}\text { Persentase } \\
(\%)\end{array}$ \\
\hline$<30$ & 5 & 83,33 \\
$>=30$ & 1 & 16,67 \\
Jumlah & 6 & 100 \\
\hline
\end{tabular}

Berdasarkan tabel 3 didapatkan hasil penelitian bahwa sebagian besar responden membutuhkan waktu $<30$ menit (83,33\%). Sehingga bisa dikatakan ASIP aman untuk dibawa perjalanan dari kantor menuju rumah masing - masing.

e. Paritas Responden

Tabel 4 Distribusi responden berdasarkan paritas

\begin{tabular}{ccc}
\hline Paritas & Frekuensi & $\begin{array}{c}\text { Persentase } \\
(\mathbf{\%})\end{array}$ \\
\hline Primipara & 1 & 16,67 \\
Multipara & 5 & 83,33 \\
Jumlah & 6 & 100 \\
\hline
\end{tabular}

Berdasarkan tabel 4 didapatkan hasil penelitian bahwa sebagian besar responden Multipara 5 orang $(83,33 \%)$. Hasil penelitian yang dilakukan oleh Fajarsari (2015), paritas mempunyai pengaruh kepada pengalaman ibu dalam mengasuh anak, pengalaman yang diperoleh memberikan pengetahuan dan keterampilan serta dapat mengembangkan kemampuan dalam mengambil keputusan. Jumlah anak sebelumnya akan mempengaruhi pengetahuan ibu dalam tindakan mengasuh anak berikutnya. Pengalaman pernah mengasuh anak dan memberikan ASI akan berdampak terhadap pandangan, sikap, dan tindakan ibu pada anak berikutnya

\section{Keasaman}

Hasil dari analisa keasaman ASI selama penyimpanan menunjukkan bahwa adanya perubahan yang berragam diantara ASI fresh, ASI yang disimpan dalam cooler bag dan yang dipasteurisasi. ASI fresh menunjukkan bahwa rata - rata kisaran $\mathrm{pH}$ ASI berkisar pada $\mathrm{pH} 7,1$ sampai dengan 7,5. ASI yang disimpan dalam cooler bag menunjukkan bahwa rata - rata kisaran $\mathrm{pH}$ ASI berkisar pada $\mathrm{pH} 5,5$ sampai dengan 5,9. Sedangkan pada ASI yang dipasteurisasi rata - rata kisaran $\mathrm{pH}$ ASI berkisar pada $\mathrm{pH} 7,1$ sampai dengan 7,7. Perubahan keasaman ini dapat disebabkan oleh bakteri yang terdapat pada ASI selama dilakukan penyimpanan. Bakteri tersebut mampu memetabolir laktosa menjadi asam laktat yang menyebabkan penurunan keasaman ASI.

Menurut Murti (2014), bahwa $\mathrm{pH}$ susu ternak netral yakni antara 6,6 sampai dengan 6,8, kecuali susu unta dan ASI 7,01. Pada pH sekitar ini mikroba khusus bakteri asam laktat mesofilik sangat cepat beradaptasi dan berkembang biak.

2. Perbedaan Keasaman ASI pada Penyimanan Hari ke 0 dan Hari ke 1

Tabel 5. Deskripsi Keasaman (pH) ASI berdasarkan Lama Penyimpanan

\begin{tabular}{|c|c|c|c|}
\hline \multirow[t]{2}{*}{$\begin{array}{l}\text { Responde } \\
\text { n }\end{array}$} & \multirow[t]{2}{*}{$\begin{array}{l}\text { Tempat } \\
\text { Penyimpana } \\
\text { n }\end{array}$} & \multicolumn{2}{|c|}{$\begin{array}{c}\text { Lama } \\
\text { penyimpana } \\
\mathbf{n}\end{array}$} \\
\hline & & $\begin{array}{c}0 \\
\text { hari }\end{array}$ & $\begin{array}{c}1 \\
\text { hari }\end{array}$ \\
\hline \multirow{3}{*}{$\begin{array}{l}\text { Responden } \\
1\end{array}$} & Fresh & 7,3 & 5,9 \\
\hline & Cooler bag & 7,1 & 5,9 \\
\hline & $\begin{array}{l}\text { Cooler bag } \\
\text { pasteurisasi }\end{array}$ & 7,4 & 5,9 \\
\hline Responden & Fresh & 7,2 & 5,7 \\
\hline
\end{tabular}


2

\begin{tabular}{|c|c|c|c|}
\hline & Cooler bag & 7,8 & 6,3 \\
\hline & Cooler bag & 7,6 & 6,7 \\
\hline Responden & Fresh & 7,5 & 5,7 \\
\hline & Cooler bag & 7,8 & 6,7 \\
\hline & $\begin{array}{l}\text { Cooler bag } \\
\text { pasteurisasi }\end{array}$ & 7,6 & 6,3 \\
\hline Responden & Fresh & 7,1 & 6,6 \\
\hline & Cooler bag & 7 & 6,6 \\
\hline & $\begin{array}{l}\text { Cooler bag } \\
\text { pasteurisasi }\end{array}$ & 7,1 & 6,6 \\
\hline Responden & Fresh & 7,5 & 5,5 \\
\hline & Cooler bag & 7,4 & 5,9 \\
\hline & $\begin{array}{l}\text { Cooler bag } \\
\text { pasteurisasi }\end{array}$ & 7,4 & 6,1 \\
\hline Responden & Fresh & 7,4 & 5,5 \\
\hline & Cooler bag & 7,5 & 5,6 \\
\hline & $\begin{array}{l}\text { Cooler bag } \\
\text { pasteurisasi }\end{array}$ & 7,7 & 6 \\
\hline
\end{tabular}

ASI mengandung laktosa yang tinggi sehingga menjadi media yang disukai oleh bakteri salah satunya bakteri asam laktat. Bakteri asam laktat adalah kelompok bakteri yang mampu memfermentasikan laktosa menjadi asam laktat. Efek bakterisidal dari asam laktat berkaitan dengan penurunan $\mathrm{pH}$ ASI menjadi 3- 4,5 sehingga pertumbuhan bakteri lain termasuk bakteri pembusuk akan erhambat, pada umumnya mikroorganisme dapat tumbuh pada pH 6-8. Penelitian Aminah (2012) menunjukkan bahwa keasaman pada ASI yang telah disimpan selama lima hari dengan suhu $-5^{\circ} \mathrm{C}$ mengalami perubahan. Perubahan keasaman ini dapat disebabkan oleh bakteri yang terdapat pada ASI selama penyimpanan. Bakteri tersebut mampu memecah laktosa menjadi asam laktat, sehingga kondisi tersebut menyebabkan penurunan keasaman ASI pada hari kelima. Penelitian juga pernah dilakukan oleh Siahaya, (2017) yang menunjukkan bahwa perlakuan lama waktu penyimpanan beku memberikan pengaruh yang nyata terhadap kadar protein, $\mathrm{pH}$, jumlah total bakteri ASI yang disimpan selama dua belas hari pada freezer. Juga terdapat pengaruh penyimpanan pada almari pendingin (suhu $2-8^{\circ} \mathrm{C}$ ) terhadap penurunan kadar laktosa dalam ASI (Arifin, dkk., 2009)

Perubahan keasaman $(\mathrm{pH})$ dapat disebabkan oleh keberadaan bakteri yang terdapat pada ASI selama penyimpanan. Murti (2014) mengemukakan bahwa $\mathrm{pH}$ susu ternak netral yakni antara 6,6-6,8, kecuali susu unta dan ASI 7,01. Pada $\mathrm{pH}$ sekitar ini mikroba khusus bakteri asam laktat mesofilik sangat cepat beradaptasi dan berkembang biak. Menurut Estiasih dan Ahmadi (2011) pada suhu pembekuan normal $\left(-18^{\circ} \mathrm{C}\right)$, terjadi penurunan mutu yang lambat akibat perubahan kimiawi atau aktivitas enzim. Perubahan tersebut dipercepat dengan perubahan $\mathrm{pH}$, peningkatan konsentrasi solute disekitral es, penurunan aktivitas air, dan potensi reduksi-oksidasi.Jika enzim tidak diinaktivasi sebelum pembekuan, kerusakan membran sel menyebakan enzim kontak dengan solut dan bereaksi.

Keasaman (PH) merupakan ukuran kekuatan suatu asam. $\mathrm{pH}$ suatu asam dapat ditera dengan beberapa cara antara lain dengan jalan menitrasi larutan dengan asam-basa dengan kertas indikator atau lebih teliti lagi dengan $\mathrm{pH}$ meter. Suatu asam kuat dalam larutan mengion sempurna menjadi ion-ionnya. Makin rendah keasaman larutan maka $\mathrm{pH}$-nya makin besar (Martoharsono dan Sugiyono, 1992). 
Susu segar $\mathrm{pH}$ nya $6.5-6.6$ bersifat agak asam, keasam susu segar berhubungan dengan fosfat susu, protein (kasein dan albumin), serta sejumlah kecil $\mathrm{CO} 2$ dan substrat yang tedapat dalam susu (Muchtadi dan Sugiyono,1992).

\section{SIMPULAN}

Ada perbedaan keasaman ASI yang disimpang selama 0 hari dan 1 hari. Disarankan kepada para ibu pekerja agar dapat memberikan ASIP kepada bayi mereka dengan penyimpanan dan pemberian dengan baik dan benar. Hasil ini dapat diaplikasikan dalam kehidupan sehari - hari ataupun dijadikan bahan acuan atau data dasar bagi para peneliti selanjutnya mengenai ASIP. Disarankan kepada instansi tempat ibu bekerja agar mengajarkan dan mengingatkan para ibu pekerjanya tentang ASIP. Sehingga para ibu pekerja dapat memberikan hak ASI eksklusif kepada bayinya.

\section{DAFTAR PUSTAKA}

Aminah, S. dan J.T. Isworo. 2012. Pengaruh Penyimpanan Pada Suhu Rendah Terhadap Umur Simpan dan Total Bakteri Air Susu Ibu. Prosiding Hasil Seminar Nasional. Lembaga Penelitian Universitas Muhammadiyah Semarang.

Arikunto, Suharsini. 2006. Prosedur Penelitian Suatu Pendekatan Praktik. Jakarta : Rineka Cipta

Dinas Kesehatan Provinsi Jawa Tengah. 2015. Profil Kesehatan.

Fazriyati, Wardah. Jangan Asal Menyimpan ASI, Ikuti Metodenya. http://female.kompas.com/read/2010/0 9/03/1501441/jangan.asal.simpan.asi.p erah.ikuti.metodenya. Diakses pada 3 September 2010.

Herawati H. 2008. Penentuan Umur Simpan pada Produk Pangan. Jurnal Litbang Pertanian. Bogor : Kementrian Pertanian-Republik Indonesia.

Muchtadi, T.R, Sugiyono, F. Ayustaningwarno. 2010. Ilmu Pengetahuan Bahan. Bandung : Penerbit Alfabeta.

Murti, T. W., 2014. Pangan, Gizi dan Teknologi Susu. Yogyakarta : Gadjah Mada University Press

Peraturan Bersama Menteri Negara Pemberdayaan Perempuan, Menteri Tenaga Kerja dan Transmigrasi dan Menteri Kesehatan Nomor 48/MEN.PP/XII/2008, PER.27/MEN/XII/2008 dan 1177/MENKES/PB/XII/2008 tentang Peningkatan Pemberian Air Susu Ibu Selama Waktu Kerja di Tempat Kerja

Muchtadi, T,R, dan Sugiyono. 1992. Petunjuk Laboratorium Ilmu Pengetahuan Bahan Pangan. IPB, Bogor.

Soetjiningsih. 1997. ASI Petunjuk untuk Tenaga Kesehatan. Jakarta: Penerbit Buku Kedokteran EGC. 